University for Business and Technology in Kosovo

UBT Knowledge Center

UBT International Conference

2012 UBT International Conference

Nov 2nd, 9:00 AM - Nov 3rd, 5:00 PM

\title{
Sustainable Architecture and Quality of Place
}

Arlinda Sheqiri

University for Business and Technology, arlinda.sheqiri@gmx.com

Follow this and additional works at: https://knowledgecenter.ubt-uni.net/conference

Part of the Architecture Commons

\section{Recommended Citation}

Sheqiri, Arlinda, "Sustainable Architecture and Quality of Place" (2012). UBT International Conference. 17. https://knowledgecenter.ubt-uni.net/conference/2012/all-events/17

This Event is brought to you for free and open access by the Publication and Journals at UBT Knowledge Center. It has been accepted for inclusion in UBT International Conference by an authorized administrator of UBT Knowledge Center. For more information, please contact knowledge.center@ubt-uni.net. 


\title{
Sustainable Architecture and Quality of Place
}

\author{
Arlinda Sheqiri ${ }^{1}$ \\ ${ }^{I}$ Department of Architecture and Spatial Planning, University for Business and Technology, \\ arlinda.sheqiri@gmx.com
}

\begin{abstract}
A major part of this challenge is the development for better city-better life and being able to create sustainable architecture solutions through more effective ways to implement in our everyday life process.

Strategists, designers and planners are also concerned with combining means and time efficiently. We can see, for example, nearly half of the city in Prishtina has faced wild development or re-development. This has happened as a result of individual construction projects which were undertook without municipal building permits because the pressure to develop was much high than capability of local authority to provide this service. Nevertheless even after twelve years from this crisis situation as a result of war this is still happening as a result of corruption. Those informal buildings are often constructed without experts (architects) by using traditional techniques and individual knowledge with threat modern ideas. The main issue under investigation and the expected contribution of this paper work is to understand the negative effects of those places at dwellers, in environment, in society education and in long term effects on global warming.
\end{abstract}

Keywords: Wellbeing, Environment, Morphology, Risk, Sustainability.

\section{Introduction}

A wide variety of sustainable possibilities exist today that can integrate in to architecture and urban design process.

On the other hand we as architects can't be only designers of two-dimension facades or three-dimension monuments but we have to find an equal eco-system not only how to design a building or a public space but also to understand the flow and possibilities of natural resources.

So we can create a comfortable system of our entire urban environment as a man made eco-system. Sometimes Sustainability is facing a misconception of how much of our existing quality of life we have to sacrifice in order to effort becoming sustainable.

From all this fundamental misunderstanding of concept for sustainability, and consequently we can see the results all around us and effects on global warming.

However developing countries are finding much more difficult to implement the basic elements of sustainability in their everyday life.

Kosovo as a developing country could be a good experimental case for offering an entirely sustainable life-style. But unfortunately the immersive ugliness of our everyday environment in Prishtina is utter chaosity made visible.

Compare to Ljubljana we can see below the differences. Slovenia is one of the countries in Europe which is considered for living in pace with nature. 


\begin{tabular}{|l|l|l|l|}
\hline City & Area & Population & Density \\
\hline Ljubljana & $163.8 \mathrm{~km}^{2}$ & 280,607 & $1,664 / \mathrm{km}^{2}$ \\
\hline Prishtina & $854 \mathrm{~km}^{2}$ & 198,214 & $230 / \mathrm{km}^{2}$ \\
\hline
\end{tabular}

The differences here is that we construct buildings which do not maximize space and redact amount of land use, we do not create intelligent buildings. For example if we see Keret House is a house build in a very narrow spot between two tall buildings in the district of Wola, Poland. The site is so narrow that it can only accommodate interior that vary between 72 centimeters and 122centimeters. Can you imagine a living space in such a narrow area?

With a creative mind, even such a small space can be used as functional house. Such intelligent design is indeed suitable for maximizing space and redacting amount of land used.

\subsection{The ide of Space and Sustainable Places}

Our ability to create sustainable places that are meaningful and places of quality depends entirely on our ability to define a space with buildings and integrate rhythm, functions, need, and patterns of (sustainable) architecture in order to inform who we are as a culture.

The skills to define space and create sustainable places which are worth caring about all come from a body of culture.

And in 1999 the war made us collapsed as a culture and now we can see the results all around us.

A place shouldn't tell us only where we are geographically but it has to inform us where we are in our culture, which we are and should give us a hint to where we are going.

Below we can see two examples of chaosity inside Prishtina but there are a hundred more places like this without sense of a place. Those places are valueless.
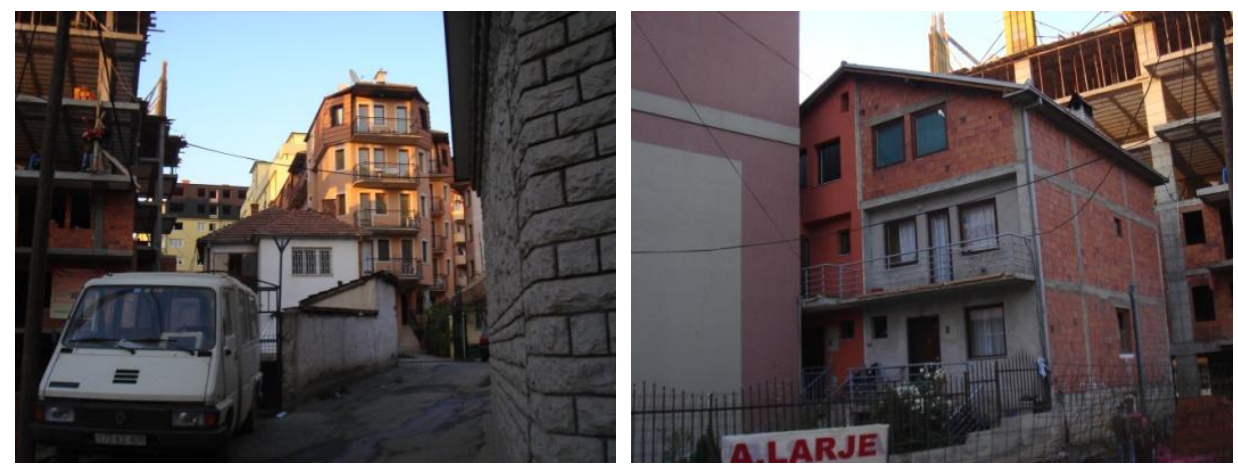

Figure 1.1: Chaosity of buildings

The need to provide a better understanding of the challenges of increasing risk and its impact on the living conditions from poor urban development, and amount of anxiety and depression that cause in our everyday life and in our children is not good for our society.

As soon as people will be aware of those effects, they will search immediately for better, healthier places to live in, and the question will be what will happen with those places we have already build.

In order to allow us to dwell in sustainable present, and environment which we build should not deprive us from ability to live in hopeful present. 
As Charles Darwin said It is not the strongest of the species that survives, nor the most intelligent that survives. It is the one that is the most adaptable to change.

With hope that we will be adaptable to change as nature requires to allow us, our future existence.
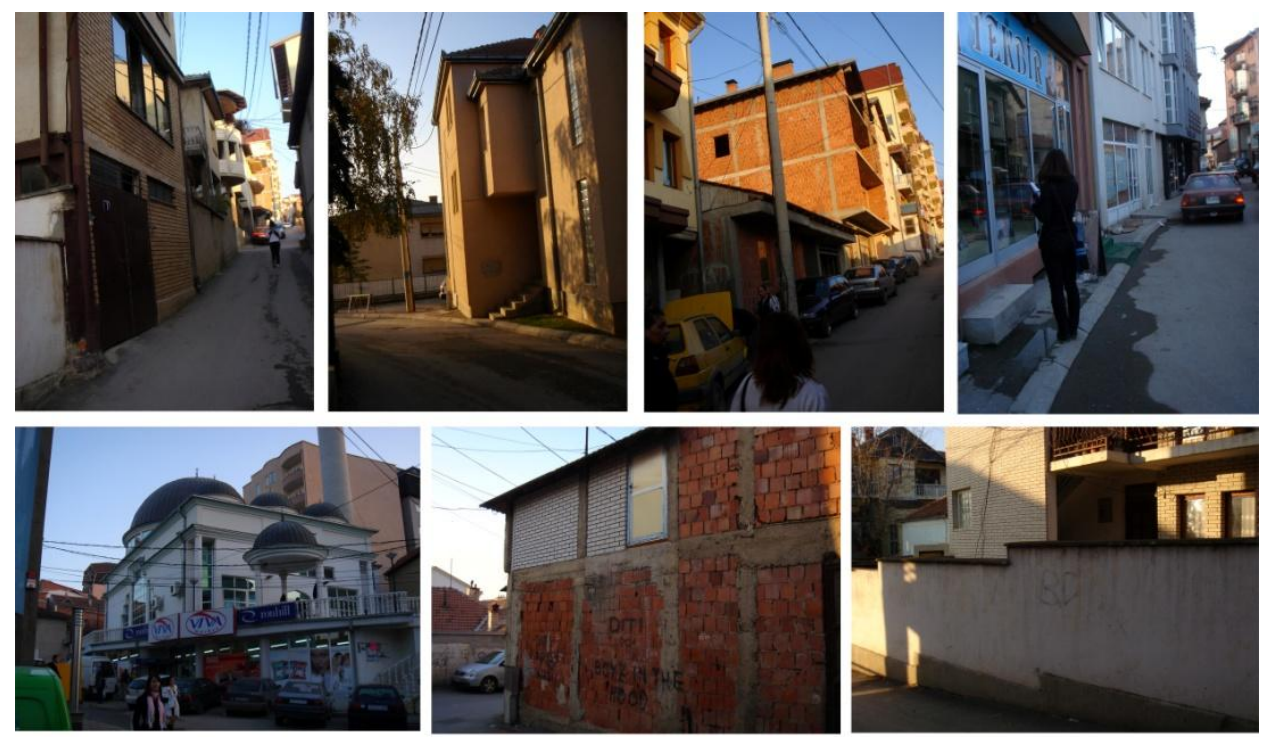

Figure 1.2: Quality of places

Table 1: Analyzing the quality of place

\begin{tabular}{|l|c|}
\hline Questions & $\begin{array}{l}\text { outcome } \\
\text { 10max }\end{array}$ \\
\hline The site allows an increase in urban density? & 1 \\
\hline $\begin{array}{l}\text { In the site are provided sharing transport, renewable energy, } \\
\text { pedestrian and cycle? }\end{array}$ & 3 \\
\hline $\begin{array}{l}\text { In the site are provided adequate services (economic, social and } \\
\text { cultural)? }\end{array}$ & 0 \\
\hline The intervention creates a good urban microclimate? & 0 \\
\hline The intervention contributes to social cohesion? & 0 \\
\hline $\begin{array}{l}\text { Roofs of buildings are used to prevent heat islands or alternative } \\
\text { energy? }\end{array}$ & 2 \\
\hline The buildings are well-oriented in terms of sunlight? & 0 \\
\hline The existing vegetation has been preserved and / or developed? & 1 \\
\hline The project creates a new biotype? & 0 \\
\hline $\begin{array}{l}\text { Is maximized reuse of building waste on site from the land } \\
\text { excavations? }\end{array}$ & 0 \\
\hline $\begin{array}{l}\text { The access and all the spaces are designed for use by the } \\
\text { weakest people? }\end{array}$ & 0 \\
\hline The volume of buildings is compact enough? & 0 \\
\hline Is respected the privacy of future residents? & 3 \\
\hline All units benefit from a good natural light? & 0 \\
\hline The facades are properly protected from the sun? & 0 \\
\hline Is planned reuse of rainwater for irrigation and gray water? & 0 \\
\hline Is the project flexible for a possible increase in volume? & \\
\hline
\end{tabular}


The analyzing work that has been done for places in figure 1.2 is presented on Table 1. To understand the quality of a place I have used a small manual of sustainable design, and outcome is evaluated from 10 points which is maximum - (best result) and 0 which doesn't full fill any of those criteria.

As Albert Einstein said "The world will not evolve past its current state of crisis by using the same thinking that created the situation".

We have to regenerate, rethink, and rebrand our places, and mostly I want to persuade you that we have to do much better if we want to continue the process of civilization and existing of our society. Being Less Bad is not good enough. In world nothings is self-sufficient everything is linked. We have to be prepared and not being sleep-walking in to the future like we are right now.

\section{References}

Francoise-Helene Jourda, (2010), "Petit manuel de la conception durable, Archibooks", France.

Michael Braunqart ed. with Willaim Mc Donough (2002) "Cradle to Cradle: Rethinking the way we make things" 